\title{
Területi és társadalmi változások a magyarországi iparvárosokban 1990-2018 között
}

\author{
The territorial and social transformation \\ of Hungarian industrial towns between 1990 and 2018
}

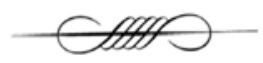

\begin{abstract}
In my study I intend to give a detailed analysis of social transformations of the past 27 years in Hungarian industrial towns (former 'socialist' towns). The array of urban functions and activities has undergone a significant modification in the so-called traditional industrial towns (11), which resulted not merely in spatial and economic structural changes but furthermore in notable social ones as well. In the case of several towns social realignments (Tatabánya, Várpalota, Oroszlány), population loss (Dunaújváros, Salgótarján), as well as the emergence of new social groups in consequence of new activities undertaken (Százhalombatta, Ajka, Várpalota) occurred. Simultaneously local community initiatives commenced with the goal of finding viable roles for these towns and their residents; for some groups within the towns, while for others temporarily or permanently through relocation to other settlements. Thus the current survey primarily concerns itself with those social issues which have initiated and brought novel changes and developments in the towns under consideration in their local economies and at various levels of their communities.
\end{abstract}

\section{KEYWORDS}

industrial cities, social and territorial change, urbanization, development

DOI 10.14232/belv.2019.2.10 https://doi.org/10.14232/belv.2019.2.10

Cikkre való hivatkozás / How to cite this article: Területi és társadalmi változások a magyarországi iparvárosokban 1990-2018 között. Belvedere Meridionale 31. évf. 2. sz. 163-172. pp. 
(Creative Commons) Nevezd meg! - Így add tovább! 4.0 (CC BY-SA 4.0)

(Creative Commons) Attribution-ShareAlike 4.0 International (CC BY-SA 4.0)

www.belvedere-meridionale.hu

\section{BEVEZETŐ}

Az iparváros elnevezés a magyarországi szakirodalmakban kettős megközelítésű; egyfelől jelenti a szocialista iparosítás által létrehozott városokat, másfelől azokat a napjainkban új beruházással rendelkező városokat, amelyek egy-egy nagyobb gyárra (például autógyárra) épültek és biztosítanak munkát a helyben, valamint a környéken élők számára. A jelen tanulmány a korábbi, szocialista iparosítás során létrejött városok jelenkori helyzetét, helyi társadalmuk lakosságszámarányának változását állítja középpontba.

Az 1950-es években a városépítés legfeltünőbb akciója az ún. szocialista városok építése volt. E városok egy-egy ipari nagyberuházás munkaerő-szükségletét voltak hivatva biztosítani. ${ }^{1}$ A nagyberuházások zöme a bányakincseket nyújtó középhegységek területén, a Borsod-AbaújZemplén megyétől (Ózd, Kazincbarcika, Miskolc) Budapesten át Veszprém megyéig (Várpalota, Ajka) húzódó energetikai, nehézipari tengely mentén történt. ${ }^{2}$

A ,szocialista városok” építésének első hullámában kezdtek hozzá Dunaújváros, Kazincbarcika, Komló, Oroszlány, Ajka felépítéséhez.

Ezekre a településekre (Oroszlány, Komló, Ajka, Várpalota, Berente, Gyöngyösvisonta), illetve az új olajtartalékokra (Százhalombatta) erőművek épültek. Nagyarányú rekonstrukcióval bővült a vas- és acélkohászati bázis (Diósgyőr és Ózd), Dunaújvárosban pedig újak jöttek létre. Oroszlányban barnaszénbányászat és villamosenergia-termelést biztosító hőerőmű, Ajkán szénbányászat, timföldgyártás és energiatermelés, Várpalotán szén- és lignitbányászat, villamosenergiatermelés és alumínium kohászat, Kazincbarcikán szénbányászat, villamosenergia-termelés és vegyipar, Tiszaújváros esetében villamosenergia-termelést adó hőerőmű és vegyipar, Dunaújvárosban pedig vas- és acélkohászatra létesített erőmü, építőanyagipar és könnyüipar jött létre. ${ }^{3}$

Ezek a települések a kor politikai elveinek megfelelő cél végrehajtását elősegítendő eszközként jöttek létre. A „kitalálók” az ipari múlton kívül - még ha voltak is - semmiféle történelmi gyökeret nem vettek figyelembe. Az új városok megjelenésük pillanatától a „modernség szinonimái” voltak. ${ }^{4}$

A települések fejlesztések szerint is csoportosíthatóak. Ennek értelmében az alábbi osztályokat alkothatunk: az első iparvárosi csoportba Ajka, Tatabánya, Ózd, Várpalota tartozik, esetükben már egy korábban is múködő ipari tevékenységet szélesítettek ki, ehhez a csoporthoz kapcsolható a bányászváros Komló is. A második csoportba azok a települések tartoznak, amelyek nem rendelkeztek ipartörténeti gyökerekkel, egy felsőbb politikai döntésre jöttek létre. Ilyennek tekinthető Dunaújváros, Paks, Tiszaújváros és Százhalombatta.

\footnotetext{
${ }^{1}$ BeluszKy 2003.

2 ENYEDI-HoRVÁTH 2002.

3 Dragonics 1975.

${ }^{4}$ Germuska 2004.
} 
Teljesen zöldmezős beruházásként indult két kisebb község szomszédságában (melyeket később integráltak a településbe) Dunaújváros (Dunai Vasmű) és a Tiszaújváros (Tiszai Vegyi Kombinát) építése. Valamint a településhez kapcsolódóan, de azzal nem összeépülve zajlott az ipartelepítés Százhalombatta (Dunai Olajfinomító) és Paks (Paksi Atomerőmű) esetében is a másik két városhoz képest fáziskéséssel az 1960-as évek végén és az 1970-es évek elején. ${ }^{5}$

A szocialista iparvárosok létrejöttében alapvető szerepet a második világháború utáni gazdasági-társadalmi, és politikai folyamatok játszottak. Ez egyfelől függési viszonyt, másfelől új gazdasági, társadalmi és politikai életteret alakított ki, amely alapjaiban megváltoztatta Magyarország egyes szegmenseit.

A városok elfogadott hazai kategorizálását elsőként Markos György fogalmazta meg a Magyarország gazdasági földrajza címü könyvében. Hangsúlyozta, hogy egy-egy város jellegének meghatározásánál nemcsak az új, hanem a múltból örökölt funkciókat is figyelembe kell venni. ${ }^{6}$

A szocialista iparvárosok tehát felülről irányított módon, tudatosan létrejött városok, melyek lakosainak száma, a városok ipari szerepkörűvé válása előtt igen alacsonynak volt tekinthető.

\section{AZ IPARVÁROSOK HELYZETE NAPJAINKBAN}

A rendszerváltozást követően a városok erőteljes pozícióveszteséget szenvedtek, egyértelműen két település esetében nem volt látható; az 1970-ben várossá vált Százhalombatta és az 1978-ban városi rangot kapott Paks vonatkozásában. E két település a mai napig is elsősorban ipari funkcióira építve működteti városát, integrálja helyi társadalmát.

Az iparvárosok jelenkori helyzetét továbbra is múltbéli szerepük határozza meg.

Az 1940-es és 1950-es években létrejött városok közé tartozik tehát: Tatabánya (1947), Ózd (1949), Várpalota (1951), Komló (1951), Dunaújváros (1951), Kazincbarcika (1954) Oroszlány (1954), Ajka (1959). Az 1960-as és 1970-es években létrejött városok közé pedig Tiszaújváros (1966), Százhalombatta (1970) és Paks (1978). (Lásd 1. ábra.)

Az iparvárosok között elsőként városi ranggal rendelkező települések (Tatabánya, Ózd) a nehéziparra épültek. Tatabánya esetében a rendszerváltozást követően a város új szerepköröket keresett, elsősorban a területi elhelyezkedésére, meglévő szakmai potenciáljára, illetve a helyben élők tudására építve. Ennek következtében a város ipari tevékenységeiben az innovatív, kreativitást és gazdasági kooperációt igénylő iparágak telepedtek le. Ezzel nemcsak a tevékenységi köre, de a településen élők foglalkoztatottsága sem helyeződött mellékvágányra. A kezdeti nehézségek után, a 2000-es évek első felére az ún. nyugati típusú fejlődési vonalra állt rá a város, melyet támogatott földrajzi elhelyezkedése, Budapesthez és a nyugati határvonalhoz egyaránt szorosan kapcsolódó gazdasági érdekeltsége. Ipari parkja, felsőfokú oktatási intézménye és a különböző vállalkozásai egyre kedvezőbb feltételeket teremtenek a magasabb státusú lakosok letelepedésében, tartós településen maradásához.

Ózd esetében a múltra alapozott jövő kevésbé pozitív. „,Ózd ma Magyarország egyik súlyos, társadalmi és gazdasági problémákkal küzdö térségének centruma, ahol a hátrányos helyzet

\footnotetext{
${ }^{5}$ Csizmady 2013.

${ }^{6}$ Markos 1952.
} 


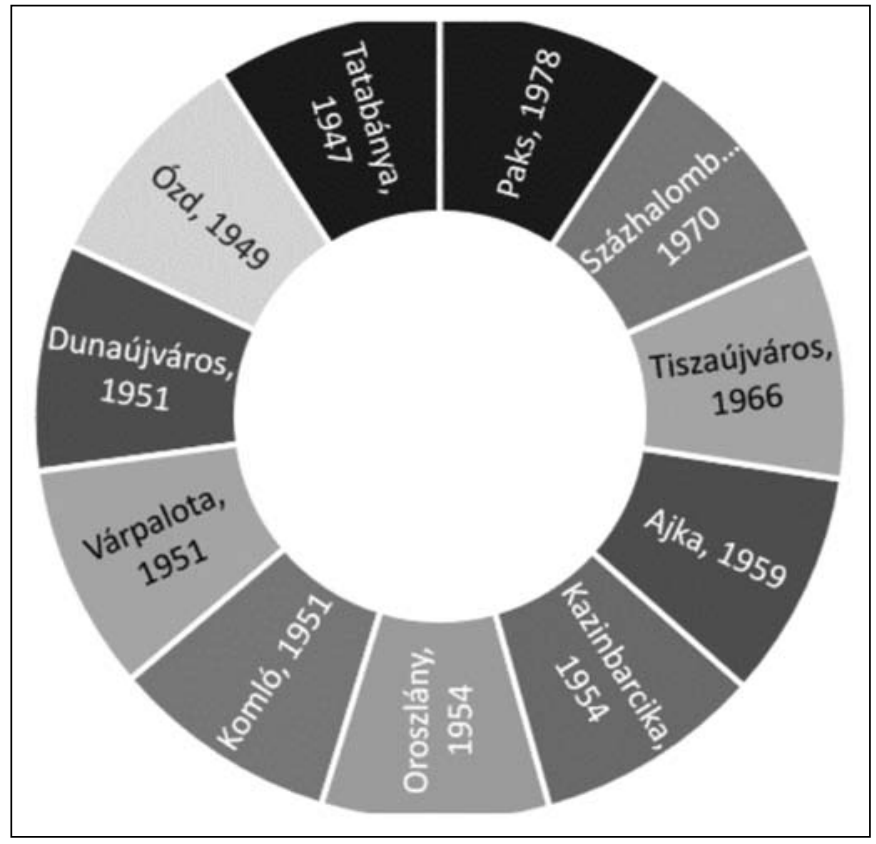

1. ÁBRA Várossá nyilvánítás éve a szocialista iparvárosok körében (Forrás: Helységnévtár adatai alapján, 2018. január 1.)

halmozódását több tényező idézte elö. ’” Az 1990-es éveket követően, a nehézipar megszünésével, a város és környékének gazdasági szerepe háttérbe szorult, mely a helyi, alacsony iskolázottságú és többnyire hátrányos helyzetű társadalom még inkább háttérbe szorult. A térség jellemzően az elmúlt közel 30 évben magas munkanélküliséggel, valamint ebből adódóan alacsony jövedelemmel rendelkezik. Az aktív gazdasági alapot biztosító szervezetek elkerülik a várost, mely még inkább háttérbe szorítják a város fejlődési útját.

Az 1951-ben városi rangot szerzett Várpalota és Komló az iparvárosok további speciális típusát mutatja. „Várpalota történelmi fejlödése a II. világháborúig töretlen, ideértve a római településtöl, a gazdag középkoron, a barokk városépitésen át egészen a 19. század végétöl kezdödően a bányászat térnyeréséig. 1951-ben »Várpalota, Inota, Pét-egy város« új korszak kezdetét hozta. A rohamos iparositás, Inota község felduzzasztása a közben már elszakadt Pétfürdövel együtt, alapjaiban formálta át a város életformáját, szerkezetét. Várpalota ipari centrummá válása a rendszerváltást követő ipari recesszió következtében nagy ürt képzett." " Az ipar szerkezeti átalakulása azonban a korábbi helyi társadalom szerkezetét is átalakította. A településen jellemzően alacsony iskolázottsági mutatójú, hátrányos helyzetű csoportok élnek, ez a város innovativitását, hosszútávú fejlődését nagymértékben befolyásolja.

\footnotetext{
${ }^{7}$ Ózd város integrált területfejlesztési stratégiája 2015.

${ }^{8}$ Várpalota Településfejlesztési Koncepció 2015-2030 2017.
} 
Komló bányásztvárosként a rendszerváltás előtti időkben gyorsan fejlődő, munkát biztosító településként volt jelen a magyarországi városok között. ,, Gazdaságára rányomja bélyegét a bányászváros múltja. A bányák bezárását követöen a mai napig nem tudták az újonnan létrejött helyi vállalkozások a munkanélkülivé vált embereket foglalkoztatni. A munkaerö képzettségi színvonala alacsony. A bánya bezárását követö nagy szociális krízist-a megerösödött helyi vállalkozások ellenére - a mai napig nem tudta kiheverni Komló és térsége." "9

A városban - hasonlóan Ózd, Várpalota településeihez - a helyben élők alacsony iskolázottsággal rendelkeznek. Komló közlekedése, elérhetősége miatt inkább az elköltözés, mint a beköltözés jellemző. A magas munkanélküliségi ráta, a hátrányos helyzet tovább nehezíti a fejlődés útját, hiszen olyan beruházásokra lenne szükség, mely újjáéleszti a város egészét. Komló esetében különösen fontos az a tény, hogy a város nem a szocialista iparosítás során vált Újvárossá, esetében már egy komoly múlttal rendelkező, bányász település fejlődött tovább. E tény azonban nem segítette abban, hogy a bányászat megszüntével kiváltságokat, vagy új perspektívákat kapjon. (Lásd 2. ábra.)

Oroszlány városa ún. zsáktelepülésként 1954 óta rendelkezik városi ranggal. A város a szénnek köszönheti fejlődését, 19-20. századi szerepét. A térség, egyben a település legnagyobb foglalkoztatója évtizedeken keresztül az erőmű és a hozzákapcsolódó Márkushegyi bányaüzem volt. A rendszerváltást követően Oroszlány gazdasági szerkezete gyökeresen átalakult, amely eredményeként az eredetileg főleg a bányászaton alapuló városban a korszerű ipari és szolgáltatási

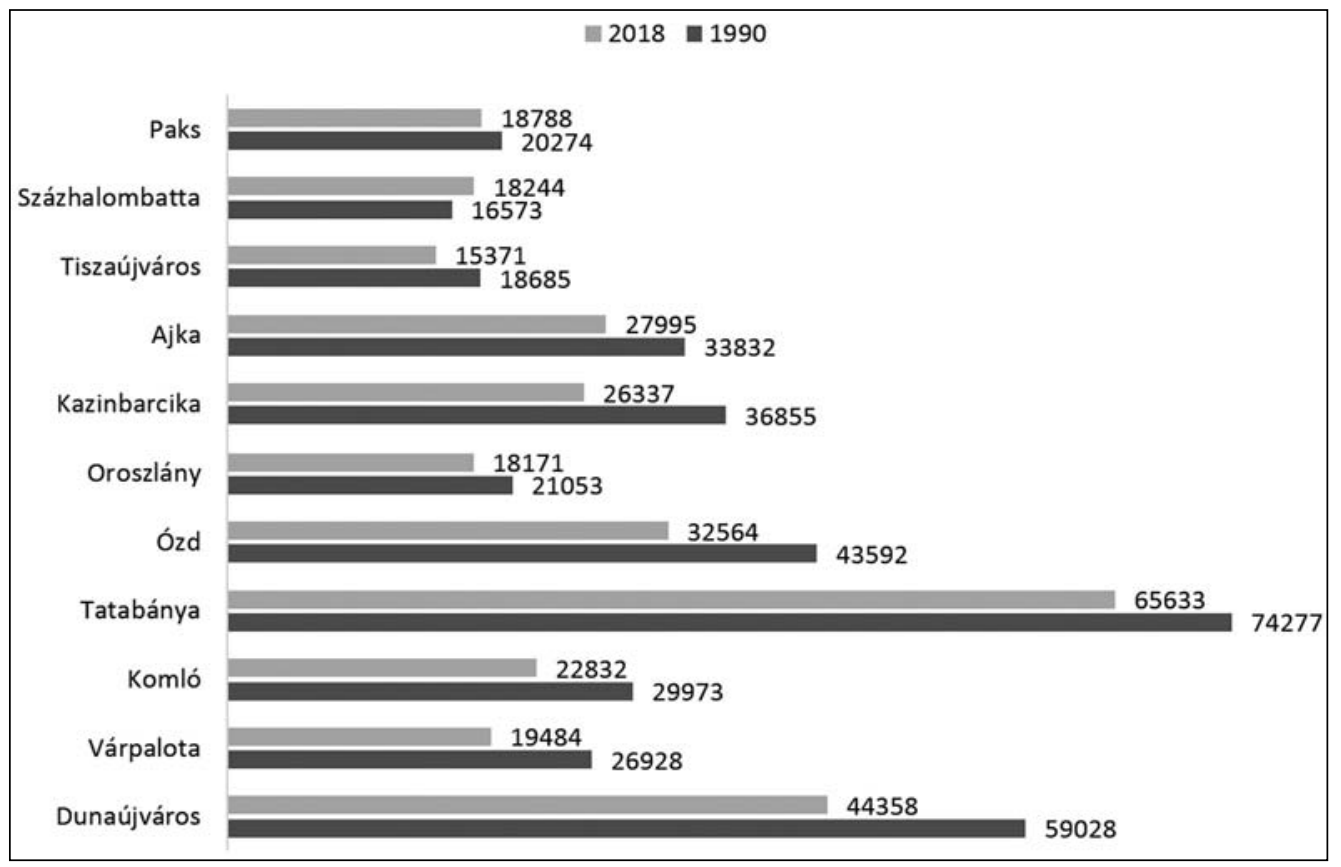

2. ÁBRA Lakosságszám változás - 1990-2018 között - a magyarországi iparvárosokban (Forrás: Helységnévtár 2018.)

\footnotetext{
${ }^{9}$ Komló integrált településfejlesztési stratégiája 2017.
} 
üzemek is betelepültek. „A 90-es években a szénbányászat átalakitására került sor, bezárásra kerültek a gazdaságtalannak itélt bányák. Az 1994-ben létrejött bányaerömü integráció az oroszlányi és tatabányai medencében még megmaradt bányákat ismét egy vállalatban egyesitette az általunk kiszolgált erőmüvekkel együtt." ${ }^{10}$ Az 1990-es éveket követően a városban jelent meg ipari park, ezzel is a város ipari tevékenységének valamilyen szintủ megtartását kívánták biztosítani. „A bányászat megszünése komoly kihivás elé állitotta, amit a város sikerrel vett: mára gazdasága a bányászattól független, stabil alapokon áll. " "1

A helyben élők társadalma itt is specifikus, a város - korábbi - bányászatra épülő ipari tevékenységének megfelelően az alap- és középfokú képzettségúek aránya az országos átlagnál magasabb, azonban a felsőfokú végzettségủek száma jelentősen alacsonyabb. Ugyanakkor az is tény, hogy a képzettség - éppen a múltbéli szerepből adódóan - nem elégíti ki a helyi munkaerőpiaci keresletet, az itt lévő intézmények, szervezetek nem minden esetben találják meg a megfelelő végzettséggel rendelkező helyi lakosságot.

Az iparvárosok korabeli és napjainkban is kiemelt szereplője Dunaújváros. A hazai iparvárosok között ezen iparváros vonatkozásában az 1990-2018 között különösen nagy volt az elvándorlás - 27 év alatt 14338 fő hagyta el a várost -, melynek oka a várost müködtető, korábbi elnevezésében Dunai Vasmü rendszerváltáskor történt megtorpanása, a munkanélküliség és a monolitikus szakmai tudás, szakmai ismeret alkalmazhatatlansága játszott szerepet.

A város az 1950-es években vált új iparvárossá a vaskohászati kombinát és a hozzá kapcsolódó lakótelep felépítésével. Mintaértékủ szocialista iparvárossá kívánták tenni a hazai városok között. 1951-1961 között Sztálinvárosként, 1961 után Dunaújvárosként több ezer munkásnak és mérnöknek biztosított helyet életének megkezdéséhez, tartós letelepedéséhez.

Az újvárosi fejlődés az 1990-es években megszakadt, mely - a többi iparvároshoz hasonlóan a nehézipar átalakuló szerepének, szerkezeti változásának volt köszönhető. A település mind tevékenységében, mind pedig helyi társadalmában nehéz évek elé nézett, melyet közel húsz éven át a bizonytalanság, a szerepkeresés jellemzett. Az ezredfordulót követően a település részben a régi ipari tevékenységének körére, részben új tevékenységekre építve megtalálta pozícióját (ISD Dunaferr Zrt., Hankook Tire Magyarország Kft. stb.). További erősítő tényező mind ebben a település Budapesthez való közelsége, kedvező térségi kulturális és oktatási szerepe.

„Kazincbarcika 1954-ben Barcika, Sajókazinc és Berente településekböl létrejött Újváros Miskolctól északra a Sajó völgyében. A város a mellé települt Borsodi Vegyi Kombinát és a közelben lévö bányászat lakóterületének kialakitására jött létre, akkor még lakótelep jelleggel, hiányos intézményi struktúrával, tervezett településként."

Az 1960-as és 1980-as évek között a város erőteljes fejlődése következtében, a Borsodi Vegyi Kombinát fejlesztésével a helyi társadalom, illetve az ôt kiszolgáló intézményrendszer a magyarországi városoktól elvárt minőséggel és teljeskörűséggel rendelkezett. Az 1980-as évek végén e város is bekerült a válság sújtotta területek közé, mely az 1990-es évek végéig folyamatosságot mutatott. A korábbi Borsodi Vegyi Kombinát helyét a BorsodChem Rt. vette át,

\footnotetext{
${ }^{10}$ Oroszlány város integrált városfejlesztési stratégiája 2010.

${ }^{11}$ Oroszlány város integrált településfejlesztési stratégiája. Megalapozó vizsgálat 2015.

${ }^{12}$ Kazincbarcika város integrált településfejlesztési stratégiájának megalapozó vizsgálata 2014.
} 
mely bár ma a térség egyik legnagyobb foglalkoztatója, a korábbi magas foglalkoztatotti kört nem képes vállalni. A település életére az iparban történt változások mellett a lakosságszámarányának változása is komoly hatást gyakorolt, illetve gyakorol napjainkban is. Kazincbarcika lakosságszáma 1990 és 2018 között több mint 10000 fővel csökkent. E csökkenés folyamatosságot mutat, melyben feltételezhető az tény, hogy a korábbi iparban foglalkoztatott, magasabb iskolai végzettséggel rendelkezők az ország különböző területeire vándoroltak, míg az alacsonyabb, képzetlenebb munkaerő helyben maradt.

Az 1950-es évek utolsó évének egyik városi rangra emelt települése Ajka volt. A több településből létrejött város az 1960-as évek végére, az 1970-es évek elejére már egy erős iparvárosként funkcionált a hazai városok között. A város gazdaságát évtizedekig a mezőgazdaság és a bányászati, alumíniumipari szektor határozta meg, a rendszerváltás után pedig egyre erőteljesebbé a feldolgozóipar vált. Az 1990-es évek után Ajka sem maradt ki az iparvárosokat sújtotta helyzetből. Szerepkeresés, új funkciók és tevékenységek keresése jellemezte a települést és térségét. Az iparban foglalkoztatottak magas arányban váltak munkanélkülivé, folyamatos elvándorlás vette kezdetét, melynek eredményeképpen 1990-2018 között több mint 5000 fővel csökkent a településen élők számaránya. E település esetében is jellemzően a középfokú vagy szakképzettséggel rendelkező lakosok vannak többségében, a felsőfokú végzettségűek száma alacsony. (Lásd 3. ábra.)

Az 1960-as és 1970-es években, az iparosítás utolsó fázisában három város került a szocialista iparvárosok körébe. Tiszaújváros (1966) korábban Tiszaszederkény, majd 1970-től Leninvárosként

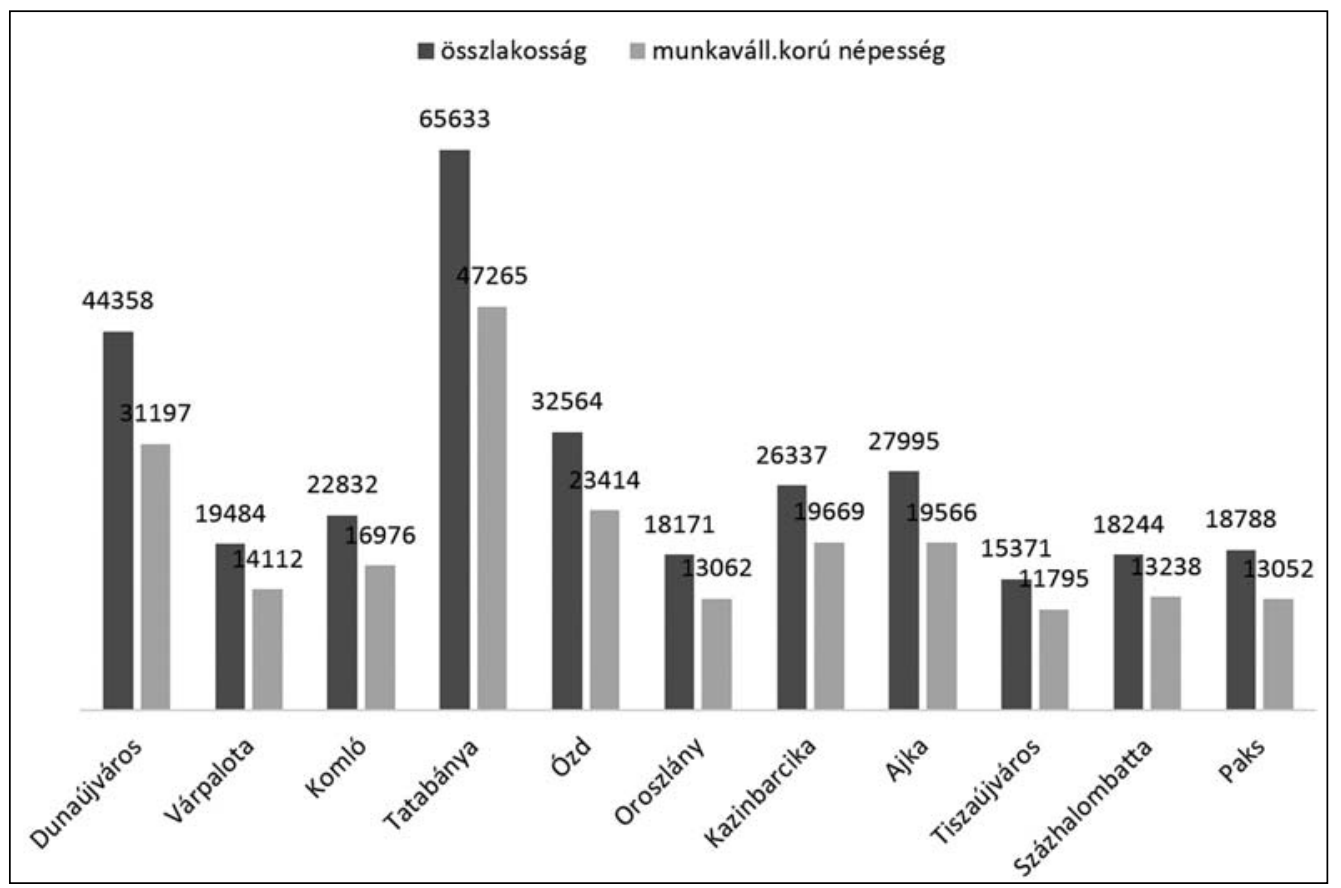

3. ÁBRA Munkavállalási korú népesség (2019. 04.) az összlakosságon belül, az összlakossággal összehasonlítva (Forrás: www.nfsz.munka.hu, Helységnévtár 2018.) 
vált ismertté a szocialista iparvárosok között. Az 1950-es évek közepén megkezdődött a Tiszai Vegyi Kombinát építése, majd az 1970-es évek elejére az olajfinomító, az 1970-es évek végére pedig felépült a Tiszai Hőerőmű. A várost, ahogyan a többi iparvárost is, hátrányosan érintette a rendszerváltás okozta ipari és társadalmi változás. A település az 1990-es években a mélypontra került, az ipari szerkezet átalakítása a helyben dolgozókat hasonlóan súlyosan érintette, mint más városok esetében. További nehezítő tényező volt, hogy a város azon lakói, akik magasabb iskolai végzettséggel, szakképzettséggel rendelkeztek elköltöztek, új életteret kerestek maguknak. Az elköltözés fokozatosan, az elmúlt közel harminc évben néhány ezres nagyságrendű volt. Százhalombatta és Paks a legkésőbb városi rangot kapott iparvárosok között jelennek meg. Az előbbi esetében az olajipari tevékenység, a második város esetében az atomerőmű a meghatározó elem. Százhalombatta modernkori ipari tevékenysége a Dunamenti Erőmű és a Dunai Finomító (ma MOL Zrt.) vállalataira épül a kezdetektől. Az 1960-as években megkezdett ipari beruházások az 1970-es évek végére biztos alapokat teremtett a foglalkoztatottaknak, a helyben élők és városba költözők részére. Százhalombatta az 1960-as évektől folyamatos fejlődési utat jár be, lakossága 1960-óta emelkedő tendenciát mutat. E város esetében elmondható, hogy a rendszerváltás nem okozott sem gazdasági, sem társadalmi törést. Az iparvárosok között egyedül e város vonatkozásában látható jelentős számarányemelkedés. A város pozícióját Budapesthez való közelsége, illetve a speciális ismeretre épülő (monolitikus) MOL Zrt., valamint a hozzá kapcsolódó kisebb gazdasági szervezetek biztosítják. A város lakossága többnyire közép vagy alapfokú végzettségü, a diplomások számaránya az iparvárosokéhoz hasonlóan alacsonyabb az országos átlagnál. Paks városa a hazai iparvárosok között némileg még inkább eltérőséget mutat. Az atomerőműre létrejövő város más vonalat követett, mint a korábban létrehozott iparvárosok. A speciális tudásra és iparra épülő város szintén egy már meglévő településre épült, a Duna menti elhelyezkedésének pozitívumaira épülve. A város iparvárossá válását az 1967-ben megszületett kormányhatározat döntötte el, mely a Duna és Csámpa-puszta között található területre helyezte az első magyarországi atomerőmű építését. 1969-től megkezdődött az ipari létesítmény létrehozása (földmunkák, lakótelepek építése, alapkőletétel). „Az atomerőmü-lakótelep a 70-es évek várostervezési elveinek megfelelöen épült. Mára a város integráns részévé vált. »Tulipános « házai miatt elindítója volt a hazai építészet egyik progressziv nyilvános vitájának. Épületei, terei ma is élhetöek, de megújításra szorulnak. "13 Mindeközben Paks lakosságszáma folyamatosan emelkedett, mely mutatót tovább emelte az a tény, amikor a települést várossá nyilvánították ki (1979), illetve megindult az első blokkban az áramtermelés (1982). A város egészének működését, lakóinak életminőségét az 1987-re elkészült erőmű biztosította és biztosítja napjainkban is. Százhalombatta és Paks közös sajátossága tehát a monolitikus ipari tevékenység. E két város jövőképét egyértelműen ez a gazdasági-politikai helyzet dönti el.

\footnotetext{
${ }^{13}$ Paks a város jövője - a jövő városa 20172017.
} 


\section{ÖSSZEGZÉS}

Összességében elmondható, hogy a hazai iparvárosok az 1990-2018 közötti időszakban folyamatos változásra kényszerülnek. A legkorábban létrejött városok még mindig erőteljesen magukon viselik ipari múltjukat, mely nagymértékben határozza meg jelenkori müködésüket, szerepüket. E szerepben azonban már a 11 város közül csak néhány volt képes helyi lakosságát egészében vagy részben megtartani, köszönhetően sajátos ipari tevékenységének, új karakterének (Paks, Százhalombatta, Tiszaújváros, Tatabánya és az elmúlt években már Dunaújváros). E városok esetében felmerülhet az a kérdés, vajon létrejöttük ideje, helyzetük, pozícióik és speciális ipari funkcióik határozták-e meg e relatív stabilnak tekinthető státusukat vagy az ehhez kötődő politikai döntések sora. Mennyire lesznek kitéve azoknak a változásoknak, melyeket a politika (szakpolitika) generál vagy a többi magyarországi városok sorában képesek lesznek megtalálni megfelelő helyüket. Vajon az 1940-es és 1950-es években létrejött, nehéziparra épült szocialista iparvárosok miért nem kerültek ehhez a listához. Komló, Ózd, Kazincbarcika képes lesz-e valaha olyan tevékenységet találni, mellyel helyi társadalmát, annak foglalkoztatását stabilizálja, hosszútávú életkilátásokat biztosítva.

A városok helyi társadalmát erőteljesen a munkás, illetve a középfokú végzettséggel rendelkezők alkotják, egy-egy város esetében a helyben élők között esetenként előfordul a magasabb iskolai végzettség (a helyben müködő felsőoktatási intézmények miatt), de alapvetően a korábban létrejött iparvárosokban alacsonyabb iskolázottsági mutatókkal találkozhatunk, mint az 1970-es években „,keletkezettek” körében.

A 11 iparvárosok esetében csak egy település növelte lélekszámát az elmúlt években, évtizedekben. Százhalombatta városa az élhetőség elve mellett maradt meg továbbra is hagyományos iparvárosnak, melyre legjobb bizonyíték, hogy a várostól független MOL Zrt-ben még mindig a helyben élők közel 50\%-a dolgozik.

Mindez a többi város esetében csak részben mondható el, így az iparvárosokra oly jellemző helyben foglalkoztatottakra való építkezés már gyengíti azt a gondolatot, hogy Magyarországon vannak még ún. hagyományos iparvárosok, ahol a megélhetést a helyben lévő ipar biztosítja a helyben élő embereknek.

\section{FELHASZNÁLT IRODALOM}

Ajka város integrált területfejlesztési stratégiája. I. Megalapozó vizsgálat. (2015) Ajka-BudapestSzékesfehérvár. 190. https://www.ajka.hu/upload/Ajka_ITS_megalapozo_elfogadott20150929.pdf. A nyilvántartott álláskeresők száma a tartózkodási helyük szerint, településenként (2019.04. havi állapot szerint) https://nfsz.munka.hu/Documents/nfsz_stat_telepulessoros_adatok_2019_04.pdf.

BELUSZKy PÁL (2003): Magyarország településföldrajza. Általános rész. Budapest-Pécs, Dialóg Campus.

Cserna GÁbor (2015): Dunaújváros. Dunaújváros Megyei Jogú Város Önkormányzata. https://dunaujvaros.hu/sites/all/files/dokumentumok/kiadvany/dunaujvaros_2_.pdf. 
CSIZMADY ADRIENNE (2013): Új városok - régi városok: összehasonlító elemzés. In SzIRMAI V. (szerk.): Csinált városok a XXI. század elején: Egy „új” városfejlődési út ígérete. Budapest, MTA Társadalomtudományi Kutatóközpont Szociológiai Intézet. 215-251.

Dragonics TAMÁs et al. (szerk.) (1973): Városépités Magyarországon a felszabadulás után. Budapest, Müszaki Könyvkiadó.

Dunaújváros integrált településfejlesztési stratégiája. (2014). Dunaújváros. file://C:/Users/User/ AppData/Local/Packages/Microsoft.MicrosoftEdge_8wekyb3d8bbwe/TempState/Downloads/ $14778 \% 20(1)$.pdf.

Enyedi György - HorvÁth György (2002:) Táj, település, régió. Budapest, MTA TK Kossuth Kiadó.

GermusKa PÁl (2004): Indusztria büvöletében. Fejlesztéspolitika és a szocialista városok. Budapest, 1956-os Intézet Közalapítvány.

Kazincbarcika város integrált településfejlesztési stratégiájának megalapozó vizsgálata. (2014). Kazincbarcika. http://kazincbarcika.hu/data/dokumentumok/its_megalapozovizs2.pdf.

Komló integrált településfejlesztési stratégiája. (2017). Budapest, Terra Stúdió Kft. www.komlo.hu/ letoltes/its.pdf.

MARKOS GYÖRGY (1962): Magyarország gazdasági földrajza. Budapest, Közgazdasági és Jogi Kiadó. Oroszlány város integrált városfejlesztési stratégiája. (2010). oroszlány/Oroszlányi Szolgáltató Zrt. http://oroszlanypark.hu/wp-content/uploads/docs/ivs/01-02.pdf.

Oroszlány város integrált településfejlesztési stratégiája I. Megalapozó vizsgálat. (2015) OroszlányBudapest-Székesfehérvár. http://oroszlanypark.hu/wp-content/uploads/docs/its/01.pdf.

Ózd város integrált területfejlesztési stratégiája (2015). https://ozd.hu/content/cont 575e73f4e57191. 23649128/ozd_integralt_telepulesfejlesztesi_strategia.pdf.

Paks a város jövője - a jövő városa. (2017) Paks Város Önkormányzatának városfejlesztési kiadványa. http://paks.hu/downloads/4447/.

Paks integrált településfejlesztési stratégiája. I. kötet: Megalapozó vizsgálat. (2016). Budapest, Terra Stúdió Kft. http://paks.hu/downloads/3954/.

Tatabánya gazdasága. http://tatabanya.hu/fooldal/felso_menu/varosunk/gazdasag.

Tiszaújváros integrált településfejlesztési stratégiája megalapozó vizsgálat. (2015). http://varoshaza. tiszaujvaros.hu/images/stories/tartalom/2015/its/megalaozo_vizs.pdf.

Várpalota Településfejlesztési Koncepció 2015-2030. (2017). http://www.varpalota.hu/wp-content/ uploads/2017/04/Várpalota-Város-Településfejlesztési-Koncepciója.pdf. 